\title{
KARAKTERISTIK TEPUNG BERAS HASIL PERLAKUAN KOMBINASI GELOMBANG MIKRO, ULTRASONIKASI DAN PEMANASAN LEMBAB
}

\author{
[Characteristics of Modified Rice Flour by Combination of Microwave, \\ Ultrasonication with Heat Moisture Treatments]
}

\author{
Shinta Dewi Ardhiyanti ${ }^{1,3)}$, Adil Basuki Ahza ${ }^{2) \star}$, Didah Nur Faridah' ${ }^{2)}$, dan Bram Kusbiantoro ${ }^{3)}$ \\ 1) Program Studi IImu Pangan, Sekolah Pascasarjana, Institut Pertanian Bogor, Bogor \\ 2) Departemen Ilmu dan Teknologi Pangan, Fakultas Teknologi Pertanian, Institut Pertanian Bogor, Bogor \\ 3) Balai Besar Penelitian Tanaman Padi (BB Padi), Subang
}

Diterima 16 Oktober 2016 / Disetujui 15 Desember 2016

\begin{abstract}
Broken and brewer rice as by product of rice milling can be developed into a functional product with higher economic value, i.e. higher resistant starch (RS) rice flour. This research was aimed to study the modification of broken and brewer rice flour by the combination of microwave and ultrasonication with heat moisture treatment (HMT) to enhance RS contents and its associated microstructural and pasting characteristics changes. The results showed that five modified rice flours that had the highest $R S$ contents were ultrasonicated with $20 \%$ of moisture content-HMT 10 and 12 hours rice flours, microwaved with $20 \%$ of moisture content-HMT 10 hours rice flour, microwaved with 50\% of moisture content-HMT 8 and 10 hours rice flours. Their RS content ranged from 6.50-9.25\% which were higher than the RS content of native rice flour (1.89\%). Those five modified flours showed noticeable structural changes from the disappearance of non starch particulates, becoming more porous and larger size matrices. The pasting temperature of those modified flour increased $(0.11-9.16 \%$ from native flour's pasting temperature) and their peak viscosity decreased (47.15-71.15\% from native flour's peak viscosity). The modified flour had improved heat stability with the decrease in breakdown (88.07-100.00\% from native flour's breakdown value) and less retrogradation tendency during cooling (44.38-66.62\% from native flour's setback value). The combined treatment caused reduction of crystalinity ratio from 0.94 (native) to 0.91-0.86 (modified flour).
\end{abstract}

Keywords: flour, HMT, microwave, rice, ultrasonication

\begin{abstract}
ABSTRAK
Beras patah dan menir sebagai produk samping penggilingan padi dapat dikembangkan menjadi produk fungsional dengan nilai ekonomi yang lebih tinggi seperti tepung beras tinggi pati resisten (RS). Tujuan penelitian ini adalah untuk mempelajari peningkatan kadar RS dan karakteristik tepung beras patah dan menir yang dimodifikasi dengan kombinasi gelombang mikro-heat moisture treatment (HMT) dan ultrasonikasi-HMT. Lima tepung termodifikasi, yakni tepung beras dengan perlakuan ultrasonikasi kadar air 20\%-HMT 10 dan 12 jam, gelombang mikro kadar air 20\%-HMT 10 jam, serta gelombang mikro kadar air 50\%-HMT 8 dan 10 jam memiliki kadar RS berkisar antara 6,50-9,25\% yang lebih tinggi dari kadar RS tepung beras asli (1,89\%). Kelima tepung beras termodifikasi tersebut menunjukkan perubahan struktur mikro dengan hilang/berkurangnya partikulat non pati, permukaan yang lebih berpori serta ukuran agregat yang lebih besar. Suhu awal terbentuknya pasta dari kelima tepung termodifikasi tersebut meningkat $(0,11-9,16 \%$ dari tepung beras asli), namun viskositas puncaknya menurun $(47,15-71,15 \%$ dari tepung beras asli). Tepung termodifikasi memiliki kestabilan yang lebih baik selama pemanasan (nilai breakdown 88,07-100,00\% lebih rendah dari tepung beras asli) serta kecenderungan teretrogradasi yang lebih rendah (nilai setback 44,38-66,62\% lebih rendah dari tepung beras asli). Perlakuan kombinasi menyebabkan penurunan rasio kristalinitas dari 0,94 (tepung beras asli) menjadi 0,91-0,86 (tepung beras termodifikasi).
\end{abstract}

Kata kunci: beras, gelombang, mikro, HMT, ultrasonikasi

\footnotetext{
*Penulis Korespondensi:

Email: adil@ipb.ac.id
} 


\section{PENDAHULUAN}

Mutu fisik beras sangat ditentukan oleh persentase beras kepala. Semakin besar persentase beras kepala semakin tinggi kelas mutu beras (BSN, 2015). Upaya untuk meningkatkan kualitas beras dapat dilakukan dengan memisahkan beras kepala dari beras patah dan menir. Sebagai produk samping penggilingan, beras patah dan menir mempunyai nilai ekonomi yang rendah. Tantangan bagi pelaku usaha penggilingan beras adalah memanfaatkan produk samping tersebut. Salah satu upaya peningkatan nilai tambah beras patah dan menir adalah dengan memprosesnya menjadi tepung yang dapat dimanfaatkan sebagai bahan baku produk pangan berbasis beras dengan manfaat fungsional yang lebih besar.

Konsumsi pati yang mudah dicerna secara berlebihan pada kelompok usia dewasa dapat menjadi salah satu faktor risiko penyakit tidak menular/kronis (Birt et al., 2013). Mengkonsumsi pangan dengan kadar pati resisten yang lebih tinggi, dapat mengurangi risiko obesitas serta munculnya penyakit seperti diabetes melitus. Pati resisten memiliki struktur yang lebih kompak sehingga tidak dapat dihidrolisis oleh enzim pencernaan (Belitz et al., 2009; Birt et al., 2015). Selain dapat membatasi intake energy, pati resisten telah dibuktikan memiliki beberapa manfaat kesehatan bagi tubuh seperti mengurangi risiko kanker usus besar, membantu meregulasi metabolisme makronutrien, memperbaiki sekresi hormon (Birt et al., 2015), mengurangi level patogen dalam usus, mengurangi toksisitas cairan feses, meningkatkan sistem imun, meningkatkan pembentukan koloni Lactobacillus dan Bifidobacteria serta meningkatkan absorbsi $\mathrm{Ca}$ dan $\mathrm{Mg}$ (Brouns et al., 2002).

Pati resisten dapat dihasilkan dari proses modifikasi, baik secara kimia, enzimatis, maupun fisik. Akhir-akhir ini modifikasi pati secara fisik banyak mendapat perhatian, karena prosesnya yang tidak melibatkan bahan kimia serta lebih sederhana dibandingkan proses modifikasi enzimatis (Kaur et al., 2012). Osmotic-pressure treatment (OPT) (Pukkahuta et al., 2007) dan teknologi hidrotermal seperti heat moisture treatment (HMT) dan annealing (Cham dan Suwannaporn, 2010; Kiatponglarpa et al., 2015) merupakan contoh teknologi modifikasi pati secara fisik yang telah dilaporkan dapat meningkatkan kandungan pati resisten pada beberapa bahan makanan. Ultrasonikasi memberikan efek kavitasi yang mampu memecah rantai polimer pati sehingga berpotensi mempercepat pembentukan pati resisten (Bizkup et al., 2005). Jiang et al. (2011) melaporkan bahwa pemasakan menggunakan gelombang mikro menurunkan kecepatan hidrolisis pati jika dibandingkan dengan perebusan biasa.
Berdasarkan hasil-hasil penelitian tersebut, kombinasi teknologi ultrasonikasi dan gelombang mikro dengan teknologi hidrotermal berpotensi menjadi teknologi alternatif yang mampu meningkatkan kadar pati resisten pada tepung beras. Penelitian ini dilaksanakan untuk mempelajari kemampuan perlakuan kombinasi teknologi ultrasonikasi dan gelombang mikro dengan teknologi hidrotermal dalam meningkatkan kadar pati resisten tepung beras, dan pengaruh perlakuan kombinasi yang berhasil meningkatkan kadar pati resisten secara signifikan terhadap struktur mikro, rasio kristalinitas dan sifat pasta tepung beras.

\section{BAHAN DAN METODE}

\section{Bahan}

Beras patah dan menir varietas Ciherang merupakan hasil samping unit penggilingan padi Koperasi Karyawan BB Padi pada bulan September 2015. Sebelum digunakan, beras disimpan secara vakum dalam kemasan plastik multilayer pada suhu $4^{\circ} \mathrm{C}$.

\section{Preparasi sampel}

Beras ditepungkan sesaat sebelum diberikan perlakuan menggunakan mesin penepung kering (Cyclotec, Tecator, Denmark), kemudian disaring untuk mendapatkan tepung 100 mesh. Parameter proses pemanasan gelombang mikro dengan piringan contoh berputar (LG MS2342D, output power 450W, Korea), ultrasonikasi (Elmasonic $S$ $180 \mathrm{H}$, output power $200 \mathrm{~W}$, Jerman) serta heat moisture treatment (HMT) dipilih berdasarkan data pada penelitian yang telah dilakukan sebelumnya (Ahza et al., 2016). Pengkodean tepung berdasarkan perlakuan yang diberikan pada tepung beras asli. Kode $U$ untuk perlakuan ultrasonikasi, M untuk perlakuan gelombang mikro, dan $\mathrm{H}$ untuk perlakuan HMT. Angka setelah $U$ dan M menunjukkan kadar air perlakuan ultrasonikasi dan gelombang mikro, sedangkan angka setelah $\mathrm{H}$ menunjukkan durasi perlakuan HMT. Pengkodean tepung selengkapnya dapat dilihat pada Tabel 1.

\section{Kombinasi ultrasonikasi-HMT}

Air deion ditambahkan ke dalam tepung dan dihomogenisasi (pengaduk elektrik, Miyako, Indonesia), hingga kadar airnya \pm 20 dan $50 \%$ bobot kering (bk). Kemudian tepung dikemas dan dikelim dalam laminated aluminium foil bag dan disimpan di dalam pendingin $\left(4^{\circ} \mathrm{C}, 6\right.$ jam). Tepung diultrasonikasi dalam botol gelas bertutup, selama 15 menit pada suhu $2^{\circ} \mathrm{C}$, kemudian disimpan pada pendingin $\left(4^{\circ} \mathrm{C}, 16 \mathrm{jam}\right)$. Setelah disimpan, tepung disesuaikan kadar airnya $( \pm 30 \%$ bk), kemudian diberi perlakuan HMT dalam oven (Memmert, 
Jerman) bersuhu $90^{\circ} \mathrm{C}$ selama $6,8,10$ dan 12 jam. Setelah HMT selesai, tepung dikeringkan pada suhu oven $40^{\circ} \mathrm{C}, 6$ jam (Binder, Jerman).

Tabel 1. Pengkodean tepung berdasarkan perlakuan

\begin{tabular}{|c|c|c|c|}
\hline Kode & Perlakuan & Kode & Perlakuan \\
\hline U2OH6 & $\begin{array}{l}\text { Ultrasonikasi } \\
\text { kadar air } 20 \% \\
\text { HMT } 6 \text { jam }\end{array}$ & M2OH6 & $\begin{array}{c}\text { Gelombang } \\
\text { mikro kadar air } \\
20 \% \text { HMT } 6 \text { jam }\end{array}$ \\
\hline U2OH8 & $\begin{array}{l}\text { Ultrasonikasi } \\
\text { kadar air } 20 \% \\
\text { HMT } 8 \text { jam }\end{array}$ & M20H8 & $\begin{array}{c}\text { Gelombang } \\
\text { mikro kadar air } \\
20 \% \text { HMT } 8 \text { jam }\end{array}$ \\
\hline U20H10 & $\begin{array}{l}\text { Ultrasonikasi } \\
\text { kadar air } 20 \% \\
\text { HMT } 10 \text { jam }\end{array}$ & M2OH10 & $\begin{array}{c}\text { Gelombang } \\
\text { mikro kadar air } \\
20 \% \text { HMT } 10 \text { jam }\end{array}$ \\
\hline U2OH12 & $\begin{array}{l}\text { Ultrasonikasi } \\
\text { kadar air } 20 \% \\
\text { HMT } 12 \text { jam }\end{array}$ & M2OH12 & $\begin{array}{c}\text { Gelombang } \\
\text { mikro kadar air } \\
20 \% \text { HMT } 12 \text { jam }\end{array}$ \\
\hline $\mathrm{U} 50 \mathrm{H} 6$ & $\begin{array}{l}\text { Ultrasonikasi } \\
\text { kadar air } 50 \% \\
\text { HMT } 6 \text { jam }\end{array}$ & M50H6 & $\begin{array}{c}\text { Gelombang } \\
\text { mikro kadar air } \\
50 \% \text { HMT } 6 \text { jam }\end{array}$ \\
\hline U50H8 & $\begin{array}{l}\text { Ultrasonikasi } \\
\text { kadar air } 50 \% \\
\text { HMT } 8 \text { jam }\end{array}$ & M50H8 & $\begin{array}{c}\text { Gelombang } \\
\text { mikro kadar air } \\
50 \% \text { HMT } 8 \text { jam }\end{array}$ \\
\hline U50H10 & $\begin{array}{l}\text { Ultrasonikasi } \\
\text { kadar air } 50 \% \\
\text { HMT } 10 \text { jam }\end{array}$ & M50H10 & $\begin{array}{c}\text { Gelombang } \\
\text { mikro kadar air } \\
50 \% \text { HMT } 10 \text { jam }\end{array}$ \\
\hline U50H12 & $\begin{array}{l}\text { Ultrasonikasi } \\
\text { kadar air } 50 \% \\
\text { HMT } 12 \text { jam }\end{array}$ & $\mathrm{M} 50 \mathrm{H} 12$ & $\begin{array}{c}\text { Gelombang } \\
\text { mikro kadar air } \\
50 \% \text { HMT } 12 \text { jam }\end{array}$ \\
\hline
\end{tabular}

\section{Kombinasi gelombang mikro-HMT}

Tepung yang telah disesuaikan kadar airnya sesuai metode pada perlakuan ultrasonikasi HMT diproses dalam gelombang mikro selama 1 menit (kadar air $\pm 20 \%$ bk) dan 2 menit (kadar air $\pm 50 \%$ bk). Setelah pemanasan gelombang mikro, sampel disimpan pada pendingin $\left(4^{\circ} \mathrm{C}, 16\right.$ jam). Setelah disimpan, tepung disesuaikan kadar airnya $( \pm 30 \%$ bk), kemudian disimpan pada pendingin $\left(4^{\circ} \mathrm{C}, 6\right.$ jam). Tepung diberi perlakuan HMT dalam oven (Memmert, Jerman) bersuhu $90^{\circ} \mathrm{C}$ selama $6,8,10$ dan 12 jam. Setelah HMT selesai, tepung dikeringkan pada suhu oven $40^{\circ} \mathrm{C}, 6$ jam (Binder, Jerman).

\section{Analisis kadar pati resisten (AOAC, 2005)}

Sebanyak $100 \pm 5 \mathrm{mg}$ sampel ditimbang di dalam tabung sentrifuse $50 \mathrm{~mL}$. Kemudian ditambah $4 \mathrm{~mL}$ larutan pancreatic a-amylase (Megazyme, Irlandia) dan amiloglukosidase (AMG, Megazyme). Larutan berisi sampel dan enzim diinkubasi selama 16 jam pada suhu $37^{\circ} \mathrm{C}$ di dalam waterbath bergoyang. Setelah 16 jam tabung dikeluarkan dari waterbath, segera ditambahkan $4 \mathrm{~mL}$ ethanol dan divortek. Tabung disentrifuse (Hettich, Jerman) pada kecepatan $3000 \mathrm{rpm}$ selama 20 menit. Supernatan yang diperoleh dipisahkan dari endapan. Ethanol $50 \%$ sebanyak $2 \mathrm{~mL}$ ditambahkan ke dalam tabung sentrifuse berisi endapan. Kemudian tabung divortex dan disentrifuse dengan kecepatan dan durasi yang sama. Tahap ini dilakukan sebanyak 2 kali.

Selanjutnya endapan yang tersisa dilarutkan dengan penambahan $2 \mathrm{~mL} \mathrm{KOH} 2 \mathrm{M}$ (Merck, USA) dan diaduk pada ice waterbath menggunakan magnetic stirrer selama 20 menit untuk melarutkan bagian pati resisten. Setelahnya sampel diangkat dari ice waterbath dan ditambahkan bufer sodium asetat $1,2 \mathrm{M}(\mathrm{pH} \mathrm{3,8)}$ sebanyak $8 \mathrm{~mL}$ serta $0,1 \mathrm{~mL}$ AMG. Larutan diinkubasi pada suhu $50^{\circ} \mathrm{C}$ selama 30 menit dengan pengadukan berselang. Setelah diinkubasi selama 30 menit, tabung berisi sampel disentrifuse pada kecepatan $3000 \mathrm{rpm}$ selama 10 menit. Sebanyak $0,1 \mathrm{~mL}$ supernatant dipindahkan ke dalam tabung reaksi. Kemudian ditambahkan $3 \mathrm{~mL}$ larutan GOPOD dan diinkubasi pada suhu $50^{\circ} \mathrm{C}$ selama 20 menit. Absorbansi larutan diukur bersama blanko menggunakan spektrofotometer UVVis pada panjang gelombang $510 \mathrm{~nm}$ (Shimadzu 1800, Jepang). Blanko dipersiapkan dengan mencampur $0,1 \mathrm{~mL}$ buffer sodium asetat $100 \mathrm{mM}(\mathrm{pH}$ 4,5) dan $3 \mathrm{~mL}$ larutan GOPOD. Standar disiap-kan menggunakan $0,1 \mathrm{~mL}$ glukosa standar dengan konsentrasi $1 \mathrm{mg} / \mathrm{mL}$ (Megazyme) ditambah $3 \mathrm{~mL}$ larutan GOPOD. Selanjutnya standar diinkubasi pada suhu $50^{\circ} \mathrm{C}$ selama 20 menit. Standar diukur sebanyak 4 ulangan.

\section{Pengamatan mikro struktur tepung}

Pengamatan struktur granula pati dilakukan dengan SEM JSM-6510A/JSM-6510LA (JEOL, Jepang). Pengamatan dilakukan dengan perbesaran 1000 kali dan 6000 kali. Butiran dilapisi dengan lapisan tipis emas menggunakan auto fine coater (10 mA, 80 detik). Pemindaian struktur mikro tepung dilakukan dengan menggunakan SEM pada tegangan $15 \mathrm{kV}$.

\section{Analisis sifat pasta}

Analisis karakter pasta tepung beras dilakukan menggunakan Rapid Visco Analyser (RVA, Perten Tecmaster, Swedia). Ditimbang sebanyak $\pm 2,5 \mathrm{~g}$ tepung (bk) dalam wadah contoh RVA, kemudian ditambahkan $\pm 25 \mathrm{~g}$ aquades sehingga mencapai konsentrasi tepung 10\%. Setelah dihomogenisasi dengan pengadukan manual, sampel dipanaskan hingga $50^{\circ} \mathrm{C}$ dalam waktu 1 menit, kemudian dipanaskan hingga $95^{\circ} \mathrm{C}$ selama 4 menit, suhu dijaga tetap pada $95^{\circ} \mathrm{C}$ selama 1,5 menit. Pasta didinginkan hingga $50^{\circ} \mathrm{C}$ dalam waktu 4 menit, dan terakhir didiamkan pada suhu $50^{\circ} \mathrm{C}$ selama 2 menit. Selama proses pemanasan kecepatan pengadukan diatur pada $160 \mathrm{rpm}$. Parameter perubahan sifat pasta yang dianalisis antara lain: suhu terbentuknya pasta, viskositas puncak, breakdown, viskositas akhir dan setback (Klein et al., 2013). 


\section{Analisis FTIR}

Analisis FTIR sampel tepung beras menggunakan spektrofotometer FTIR (Tensor 37, Bruker, Jerman). Pengamatan absorbansi dilakukan pada kisaran panjang gelombang $399-3996 \mathrm{~cm}^{-1}$. Rasio absorbansi pada panjang gelombang 1047 dan $1022 \mathrm{~cm}^{-1}$ diperhitungkan untuk menentukan rasio antara struktur kristalin dan struktur amorf (Zeng $\mathrm{F}$ et al., 2015; Chung et al., 2009). Rasio absorbansi pada panjang gelombang 1022 dan $955 \mathrm{~cm}^{-1}$ diperhitungkan untuk menentukan perubahan area amorf, semakin tinggi rasio menunjukkan semakin besarnya area amorf (Htoon et al., 2009).

\section{Rancangan percobaan dan analisis statistik}

Desain percobaan yang digunakan adalah rancangan acak lengkap dengan 2 kali ulangan untuk pengukuran kadar RS sebagai respon yang diamati. Data yang diperoleh diuji beda nyata menggunakan program statistik STAR 2013 (IRRI) dengan bantuan Microsoft Excel. Apabila terdapat perbedaan yang signifikan $(P<0,05)$ maka dilakukan uji lanjut dengan Duncan's Multiple Range Tests (DMRT) pada taraf kepercayaan 95\%. Lima tepung beras termodifikasi yang memiliki kadar RS tertinggi dianalisa struktur mikro (SEM), rasio kristalinitas (FTIR) dan sifat pastanya (RVA). Analisis FTIR dan sifat pasta dilakukan 2 kali ulangan. Data yang diperoleh diuji beda nyata menggunakan program statistik STAR 2013 (IRRI) dengan bantuan Microsoft Excel. Apabila terdapat perbedaan yang signifikan $(P<0,05)$ maka dilakukan uji lanjut dengan Duncan's Multiple Range Tests (DMRT) pada taraf kepercayaan $95 \%$.

\section{HASIL DAN PEMBAHASAN}

\section{Kadar pati resisten tepung beras asli dan ter- modifikasi}

Hampir seluruh sampel dengan perlakuan kombinasi mempunyai kadar RS yang lebih tinggi dibandingkan tepung beras asli $(P<0,05)$. Tepung dengan perlakuan ultasonikasi kadar air 20\%-HMT 6 hingga 12 jam mempunyai kadar RS 2,29-6,89\%, tepung dengan perlakuan ultasonikasi kadar air 50\%-HMT 6 hingga 12 jam mempunyai kadar RS $2,56-4,02 \%$. Tepung dengan perlakuan gelombang mikro kadar air 20\%-HMT 6 hingga 12 jam mempunyai kadar RS 1,87-8,04\%, tepung dengan perlakuan ultrasonikasi kadar air 50\%-HMT 6 hingga 12 jam mempunyai kadar RS 2,22-9,25\%. Data kadar RS tepung beras asli dan termodifikasi dapat dilihat pada Tabel 2.

Peningkatan kadar RS tepung beras termodifikasi berkisar antara 17,24-389,51\% dibandingkan kadar RS tepung beras asli yang besarnya 1,89\% (Tabel 2). Persentase peningkatan maksimum kadar
RS pada penelitian ini lebih tinggi dibandingkan hasil penelitian Hung et al. (2016) pada beras beramilosa sedang dengan perlakuan HMT tunggal (kadar air $30 \%, 110^{\circ} \mathrm{C}, 8 \mathrm{jam}$ ). Persentase peningkatan kadar RS maksimum pada penelitian tersebut sebesar $267,7 \%$ dibandingkan pati beras asli. Suhu HMT yang lebih tinggi pada penelitian Hung et al. (2016) menyebabkan lebih rendahnya peningkatan kadar RS pada penelitian tersebut. Suhu, kadar air dan durasi HMT mempengaruhi daya cerna pati termodifikasi (Hoover, 2010). Kadar air yang terbatas pada tahapan HMT menyebabkan perubahan struktur pati. Air dalam granula membuat sebagian molekul pati berotasi, sehingga membentuk ikatan hidrogen lebih banyak. Konformasi tersebut menghasilkan pati termodifikasi dengan struktur double helix yang lebih teratur dan resisten terhadap amilolisis (Zhou et al., 2014).

Tabel 2. Kadar RS tepung dengan perlakuan kombinasi ultrasonikasi-HMT dan gelombang mikro HMT

\begin{tabular}{lccc}
\hline Tepung & $\begin{array}{c}\mathrm{RS} \pm \mathrm{SD} \\
(\% \mathrm{bk})\end{array}$ & Tepung & $\begin{array}{c}\mathrm{RS} \pm \mathrm{SD} \\
(\% \mathrm{bk})\end{array}$ \\
\hline Native & $1,89 \pm 0,01^{1}$ & $\mathrm{M} 2 \mathrm{H} 6$ & $1,87 \pm 0,05^{1}$ \\
$\mathrm{U} 2 \mathrm{OH} 6$ & $2,30 \pm 0,10^{\mathrm{hl}}$ & $\mathrm{M} 2 \mathrm{H} 8$ & $2,48 \pm 0,01^{\mathrm{gh}}$ \\
$\mathrm{U} 20 \mathrm{H} 8$ & $2,29 \pm 0,02^{\mathrm{hi}}$ & $\mathrm{M} 20 \mathrm{H} 10$ & $8,04 \pm 0,29^{\mathrm{b}}$ \\
$\mathrm{U} 20 \mathrm{H} 10$ & $6,89 \pm 0,11^{\mathrm{cd}}$ & $\mathrm{M} 2 \mathrm{H} 12$ & $4,92 \pm 0,38^{\mathrm{e}}$ \\
$\mathrm{U} 20 \mathrm{H} 12$ & $6,50 \pm 0,26^{\mathrm{d}}$ & $\mathrm{M} 5 \mathrm{H} 6$ & $5,08 \pm 0,16^{\mathrm{e}}$ \\
$\mathrm{U} 50 \mathrm{H} 6$ & $2,77 \pm 0,12^{\mathrm{g}}$ & $\mathrm{M} 50 \mathrm{H} 8$ & $7,22 \pm 0,02^{\mathrm{c}}$ \\
$\mathrm{U} 50 \mathrm{H} 8$ & $2,56 \pm 0,47^{\mathrm{gh}}$ & $\mathrm{M} 50 \mathrm{H} 10$ & $9,25 \pm 0,18^{\mathrm{a}}$ \\
$\mathrm{U} 50 \mathrm{H} 10$ & $4,02 \pm 0,03^{\dagger}$ & $\mathrm{M} 50 \mathrm{H} 12$ & $2,22 \pm 0,01^{\mathrm{hi}}$ \\
U50H12 & $3,84 \pm 0,35^{\dagger}$ & & \\
Keterangan: *data dengan & superscript berlainan maka \\
berbeda secara signifikan & $(P<0,05)$
\end{tabular}

Perlakuan kombinasi gelombang mikro dan HMT $90^{\circ} \mathrm{C}$ selama 10 jam pada penelitian ini lebih efektif meningkatkan kadar RS dibandingkan kombinasi perlakuan lainnya. Namun nilai tersebut masih lebih rendah dibandingkan kadar RS tepung beras termodifikasi HMT tunggal selama 12 jam pada suhu dan kadar yang sama, yakni sebesar 10,29\% (Ahza et al., 2016). Penelitian ini merupan kelanjutan dari penelitian Ahza et al. (2016). Pada penelitian Ahza et al. (2016) peningkatan durasi HMT hingga 12 jam meningkatkan kadar RS tepung beras. Pada penelitian ini peningkatan durasi HMT hingga 12 jam menyebabkan penurunan kadar RS. $\mathrm{Hal}$ ini disebabkan adanya perlakuan kombinasi yang mendahului HMT, khususnya gelombang mikro. Pada proses pemanasan gelombang mikro khususnya pada kadar air $50 \%$, tepung terlebih dahulu tergelatinisasi dan mengalami pemecahan granula pati, sehingga tepung pada perlakuan tersebut lebih terpapar oleh perlakuan HMT. Pemanasan HMT yang lebih lama (12 jam) yang didahului perlakuan gelombang mikro dapat berpengaruh 
negatif terhadap pembentukan RS dengan memperkecil berat molekul (Pratiwi, 2016), padahal untuk membentuk RS diperlukan pati dengan derajat polimerisasi $10-35$ yang merupakan ukuran pati yang paling banyak menyusun RS (Schmiedl et al., 2000).

\section{Struktur mikro granula tepung beras asli dan termodifikasi}

Citra SEM granula tepung beras asli dan tepung beras termodifikasi berupa agregat matriks pati, protein dan komponen lain (Gambar 1) yang tidak hilang selama proses penepungan kering (Leewatchararongjaroen dan Anuntagool, 2016; de Souza et al., 2016). Agregat tepung beras asli menggumpal tak beraturan dengan kisaran ukuran 1-20 $\mu \mathrm{m}$. Citra tersebut berbeda dengan bentuk polygonal/polyhendral granula pati beras asli yang memiliki kisaran ukuran 2-7 $\mu \mathrm{m}$ (Jiranuntakul et al., 2011). Agregat tepung beras termodifikasi cenderung lebih besar dibandingkan agregat tepung beras asli. Diameter agregat tepung hasil perlakuan ultrasonikasi-HMT (kadar air 20\% selama 10 jam) mencapai $45 \mu \mathrm{m}$. Pembesaran granula pati beras ketan dan non ketan juga dilaporkan oleh Anderson dan Guraya (2006) setelah diberi perlakuan HMT gelombang mikro pada kadar air $20 \%$ dengan suhu mendekati titik leleh, selama 60 menit. Agregasi akibat perlakuan HMT gelombang mikro tersebut (Anderson dan Guraya, 2006) dapat menjelaskan citra agregat yang lebih besar pada tepung termodifikasi.

Permukaan agregat tepung beras termodifikasi cenderung lebih porous dibandingkan tepung beras asli. Permukaan agregat tepung tepung beras asli nampak memiliki lebih banyak partikel non pati yang menempel dibandingkan permukaan agregat tepung termodifikasi (Gambar 1). Pada Gambar 1 terlihat adanya retakan dan lekukan akibat ultrasonikasi, sejalan dengan temuan Sujka dan Jamroz (2013). Namun perubahan struktur permukaan agregat tepung dengan perlakuan gelombang mikro-HMT pada kadar air 50\% tampak lebih nyata dengan adanya agregat yang terpecah dan permukaan yang lebih porous. Perlakuan ultrasonikasi pada suhu rendah dapat menyebabkan perubahan permukaan agregat tidak tampak begitu nyata (Pinto et al., 2015).

\section{Rasio kristalinitas tepung beras asli dan ter- modifikasi}

Spektra FTIR pada Gambar 2 menunjukkan pola yang sama antara tepung beras asli dan tepung dengan perlakuan kombinasi. Hal tersebut menunjukkan bahwa proses modifikasi yang diberikan kepada tepung beras tidak menyebabkan perubahan gugus fungsi/struktur kimia (Zeng $\mathrm{S}$ et al., 2015).

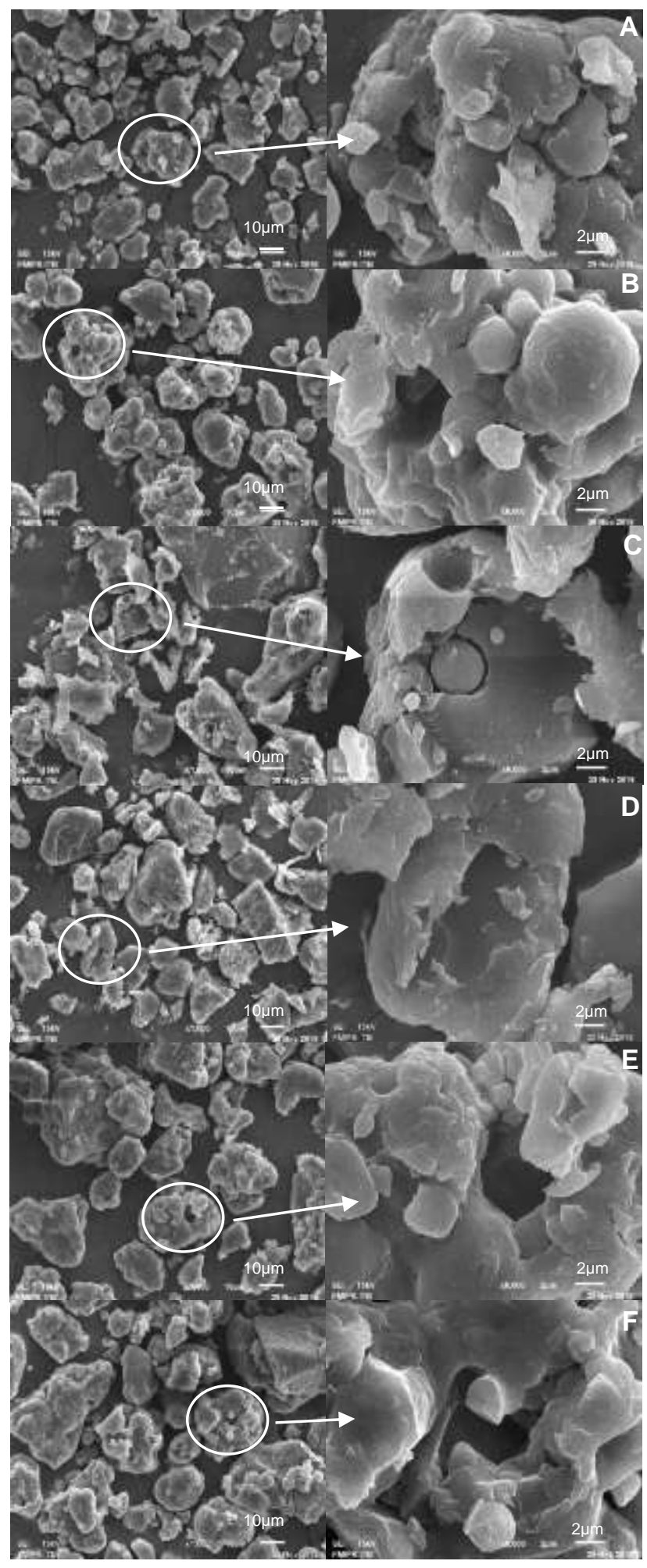

Gambar 1. Pengaruh kombinasi gelombang mikroHMT pada kadar air 20\% HMT 10 jam (B) kadar air 50\% HMT 8 jam (C) kadar air 50\% HMT 10 jam (D) dan ultrasonikasi-HMT pada kadar air 20\% HMT 10 jam (E) kadar air 20\% HMT 12 jam $(\mathrm{F})$, terhadap tepung beras asli $(\mathrm{A})$ 


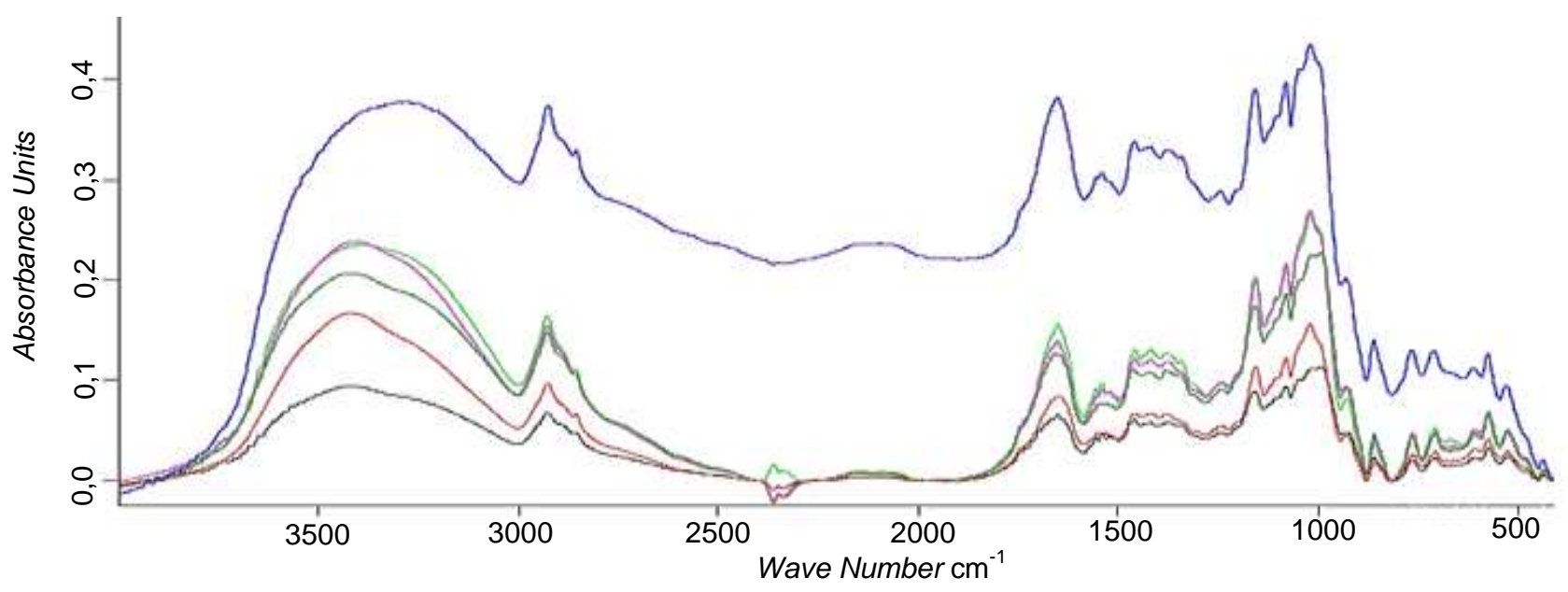

Gambar 2. Spektra FTIR tepung beras asli dan termodifikasi. Tepung beras asli (biru); tepung dengan perlakuan gelombang mikro kadar air 20\%-HMT 10 jam (hijau tua); tepung dengan perlakuan gelombang mikro kadar air 50\%-HMT 8 jam (ungu) 10 jam (merah); tepung dengan perlakuan ultrasonikasi kadar air 20\%-HMT 10 jam (hijau muda) 12 jam (hitam)

Meskipun memiliki pola yang sama, seluruh tepung dengan perlakuan kombinasi memiliki intensitas absorbansi yang lebih rendah dibandingkan tepung beras asli. Penurunan intensitas tersebut menunjukkan adanya perubahan konformasi tertentu pada tepung beras termodifikasi (Zeng S et al., 2015). Absorbansi FTIR pada panjang gelombang $1047 \mathrm{~cm}^{-1}$ meningkat dengan adanya peningkatan area kristalin, absorbansi pada panjang gelombang $1022 \mathrm{~cm}^{-1}$ meningkat dengan adanya pertambahan area amorf pati (Chung et al., 2009; Zeng $\mathrm{F}$ et al., 2015). Seperti halnya absorbansi pada panjang gelombang $1047 \mathrm{~cm}^{-1}$, absorbansi pada panjang gelombang $995 \mathrm{~cm}^{-1}$ juga meningkat dengan adanya peningkatan area kristalin (Ambigaipalan et al., 2014). Oleh karena itu rasio antara absorbansi pada panjang gelombang $1047 \mathrm{~cm}^{-1}$ dan $1022 \mathrm{~cm}^{-1}$ digunakan untuk menunjukkan jumlah relatif area kristalin terhadap area amorf (Zeng $\mathrm{F}$ et al., 2015; Warren et al., 2016), sedangkan rasio antara absorbansi pada panjang gelombang $1022 \mathrm{~cm}^{-1}$ dan 995 $\mathrm{cm}^{-1}$ digunakan untuk menunjukkan jumlah relatif area amorf terhadap area kristalin. Jumlah relatif area kristalin terhadap area amorf tepung beras asli dan tepung beras termodifikasi adalah $0,86-0,94$ (Tabel 3). Seluruh tepung dengan perlakuan kombinasi memiliki jumlah relatif area kristalin terhadap area amorf yang lebih rendah dibandingkan tepung asli $(P<0,05)$. Jumlah relatif area amorf terhadap area kristalin tepung beras asli dan tepung beras termodifikasi adalah 0,98-1,16 (Tabel 3). Berkebalikan dengan jumlah relatif area kristalin terhadap area amorf, hampir seluruh tepung termodifikasi memiliki jumlah relatif area amorf terhadap area kristalin lebih tinggi dibandingkan tepung asli $(P<0,05)$.
Penurunan rasio absorbansi $1047 / 1022 \mathrm{~cm}^{-1}$ dan peningkatan rasio absorbansi $1022 / 995 \mathrm{~cm}^{-1}$ menunjukkan bahwa terjadi perubahan konformasi pati yakni menurunnya daerah kristalin pada tepung beras termodifikasi (Zeng $\mathrm{F}$ et al., 2015, Chung et al., 2009). Berkurangnya daerah kristalin pada tepung dengan perlakuan ultrasonikasi-HMT dapat disebabkan oleh adanya air yang berdifusi ke dalam granula pati dan mengganggu konformasi pati (Jambrak et al., 2010) pada saat proses ultrasonikasi. Pada tepung beras dengan perlakuan gelombang mikro-HMT berkurangnya daerah kristalin dapat disebabkan oleh pemanasan pada saat perlakuan gelombang mikro, yang difasilitasi air pada perlakuan dengan kadar air tinggi, sehingga memungkinkan terjadinya pengembangan granula dan terganggunya konformasi kristalin tepung. Selain itu perlakuan HMT tunggal juga berpengaruh pada penurunan jumlah area kristalin pati beras (Zhou et al., 2014).

Tabel 3. Hasil analisis FTIR tepung native dan tepung termodifikasi

\begin{tabular}{lcc}
\hline Sampel & $\begin{array}{c}\text { Rasio absorbansi } \\
\text { pada 1047 dan } \\
1022 \mathrm{~cm}^{-1}\end{array}$ & $\begin{array}{c}\text { Rasio absorbansi } \\
\text { pada 1022 dan } 995 \\
\mathrm{~cm}^{-1}\end{array}$ \\
\hline Asli & $0,94 \pm 0,00^{\mathrm{a}}$ & $1,05 \pm 0,00^{\mathrm{c}}$ \\
$\mathrm{M} 2 \mathrm{H} 10$ & $0,89 \pm 0,01^{\mathrm{c}}$ & $0,99 \pm 0,01^{\mathrm{d}}$ \\
$\mathrm{M} 50 \mathrm{H} 8$ & $0,88 \pm 0,00^{\mathrm{c}}$ & $1,10 \pm 0,00^{\mathrm{b}}$ \\
$\mathrm{M} 5 \mathrm{H} 10$ & $0,86 \pm 0,01^{\mathrm{d}}$ & $1,16 \pm 0,02^{\mathrm{a}}$ \\
$\mathrm{U} 2 \mathrm{H} 10$ & $0,88 \pm 0,00^{\mathrm{c}}$ & $1,06 \pm 0,00^{\mathrm{c}}$ \\
$\mathrm{U} 2 \mathrm{H} 12$ & $0,91 \pm 0,00^{\mathrm{b}}$ & $0,98 \pm 0,00^{\mathrm{d}}$ \\
\hline
\end{tabular}

Keterangan: *data dalam satu kolom dengan superscript berlainan maka berbeda secara signifikan $(P<0,05)$ 


\section{Sifat pasta tepung beras asli dan termodifikasi}

Gambar 3 menunjukkan profil pasta tepung termodifikasi yang lebih rendah dibandingkan tepung beras. Kombinasi ultrasonik-HMT maupun gelombang mikro-HMT meningkatkan suhu awal gelatinisasi $(P<0,05)$ (Tabel 4$)$.

Temuan ini sesuai dengan hasil proses HMT yang dilaporkan oleh Zavareze et al. (2010). Peningkatan suhu awal terbentuknya pasta dan peningkatan suhu gelatinisasi kemungkinan besar disebabkan oleh proses retrogradasi dan pembentukan kristal baru yang memiliki stabilitas termal yang lebih tinggi (Klein et al., 2013). Kombinasi gelombang mikro-HMT dengan kadar air 50\%, selama 8 dan 10 jam, menurunkan kekentalan pasta puncak hingga 1209,50 dan 1094,00 cP $(P<0,05)$. Penurunan tersebut lebih drastis dibandingkan dengan kombinasi HMT pada kadar air $20 \%$, baik dengan ultrasonikasi (1914,00 dan 2003,50 cP) maupun gelombang mikro (1977,00 cP) (Tabel 4). Penurunan nilai puncak viskositas diduga akibat tingginya kerusakan dan retrogradasi pati sesuai temuan (BeMiller, 2007; Belitz et al., 2009). Hal tersebut didukung oleh hasil pengamatan citra SEM yang menunjukkan mikrostruktur sampel termodif-kasi terlihat lebih porous (Gambar 1). Tanpa kombinasi proses ultrasonikasi dan gelombang mikro, perlakuan PPL yang diberikan oleh Zavareze et al. (2010) tidak memberikan pengaruh yang signifikan terhadap puncak kekentalan pati beras.

Perbedaan antara nilai viskositas puncak dan holding viscosity (viskositas setelah suhu dijaga konstan pada $95^{\circ} \mathrm{C}$ ) disebut nilai breakdown (Mitchell, 2009). Semakin kecil nilai breakdown maka viskositas pasta semakin stabil selama pemanasan. Tepung termodifikasi memiliki nilai breakdown lebih kecil dibandingkan tepung asli $(P<0,05)$. Bahkan tepung dengan perlakuan gelombang mikro kadar air 50\%-HMT 8 dan 10 jam tidak mengalami penurunan viskositas saat dipanaskan pada suhu konstan $95^{\circ} \mathrm{C}$, sehingga nilai breakdownnya tidak dapat ditentukan (Tabel 4). Menurut Zavareze et al. (2010) nilai breakdown pati beras dengan perlakuan HMT lebih rendah dibandingkan pati asli, dengan persentase penurunan berkisar antara $28-75 \%$. Persentase tersebut lebih kecil dibandingkan persentase penurunan nilai breakdown pada penelitian ini yakni tidak terdeteksi $-92 \%$. Semakin besarnya persentase penurunan breakdown pada penelitian ini dapat disebabkan oleh kombinasi dengan perlakuan ultrasonikasi dan pemanasan gelombang mikro serta perbedaan parameter proses HMT yang digunakan. Kombinasi perlakuan menyebabkan peningkatan kekompakan struktur pati pada tepung beras sehingga penyerapan air oleh granula pati menjadi terbatas. Rendahnya penyerapan air membatasi pembengkakan granula. Granula pati dengan pembengkakan granula yang terbatas, viskositas serta tingkat disintegrasi strukturnya lebih tidak terpengaruh oleh pengadukan dan pemanasan, sehingga nilai breakdownnya kecil (Adebowale et al., 2005). Nilai setback menggambarkan kecenderungan pati untuk mengalami retrogradasi yakni proses reasosiasi molekul pati membentuk struktur kristalin selama didinginkan pada suhu $50^{\circ} \mathrm{C}$ (BeMiller, 2007). Nilai setback merupakan selisih antara nilai viskositas pada suhu $50^{\circ} \mathrm{C}$ dengan holding viscosity (Tabel 4). Seluruh tepung termodifikasi memiliki nilai setback lebih kecil dibandingkan tepung asli $(P<0,05)$.

Nilai setback pati beras dengan perlakuan HMT, lebih rendah dibandingkan pati asli, dengan persentase penurunan berkisar antara 12-52\% (Zavareze et al., 2010). Persentase tersebut lebih kecil dibandingkan persentase penurunan nilai setback pada penelitian ini yakni $44-67 \%$. Semakin besarnya persentase penurunan setback pada penelitian ini dapat disebabkan oleh kombinasi dengan perlakuan ultrasonikasi dan pemanasan gelombang mikro. Baik tepung dengan perlakuan gelombang mikro-HMT dan ultrasonikasi-HMT menunjukkan penurunan nilai setback. Penurunan nilai setback tersebut karena molekul pati telah membentuk konformasi yang lebih kompak. Hal tersebut sesuai dengan data kadar RS yang lebih tinggi. Struktur yang lebih kompak membuat kecenderungan retrogradasi menurun, karena berkurangnya jumlah amilosa terlarut yang diperlukan dalam proses retrogradasi.

Beberapa produk pangan memerlukan jenis tepung/pati yang memiliki puncak viskositas, nilai breakdown dan nilai setback yang lebih rendah. Sup instan berbentuk bubuk yang harus direhidrasi sebelum dikonsumsi, memerlukan karakteristik pati yang memiliki nilai breakdown rendah namun viskositasnya cukup tinggi sebagai pengisi seperti tepung beras dengan perlakuan ultrasonikasi-HMT dan gelombang mikro kadar air 20\%-HMT 10 jam. Sehingga saat dikonsumsi hangat sup tidak kehilangan kekentalannya. Namun karena puncak viskositas tepung tersebut tidak cukup tinggi, maka diperlukan tambahan pati lain yang mempunyai viskositas yang tinggi sehingga dalam penggunaannya tidak berlebihan. Tepung/pati yang memiliki nilai setback rendah sesuai untuk produk yang disimpan dingin seperti makanan beku. Jenis tepung yang sesuai pada penelitian ini adalah tepung dengan perlakuan gelombang mikro kadar air 50\%-HMT. 


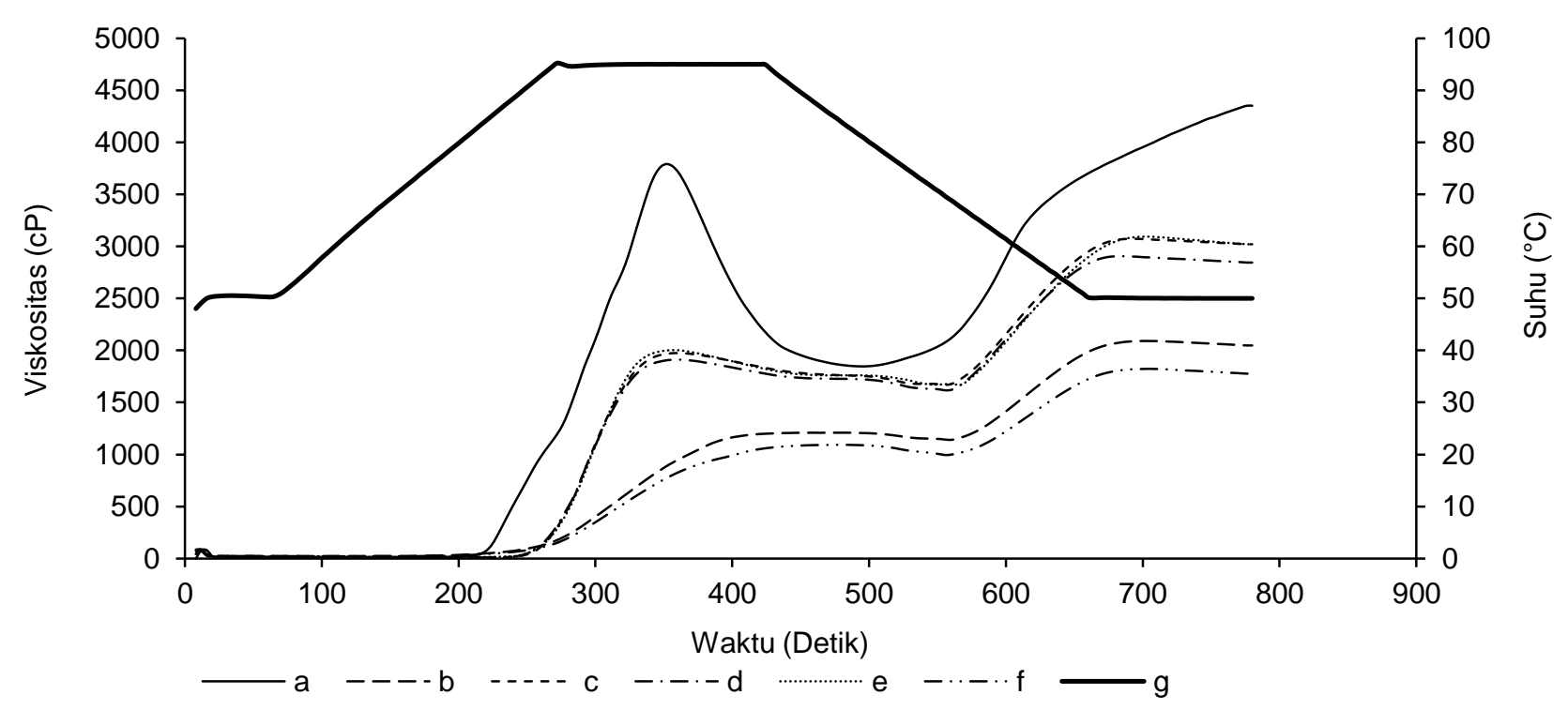

Gambar 3. Profil sifat pasta tepung beras asli (a) tepung dengan perlakuan kombinasi gelombang mikroHMT pada kadar air 50\% HMT 8 jam (b) 10 jam (f), kadar air 20\% HMT 10 jam (c) serta ultrasonikasi pada kadar air 20\% HMT 10 (d) 12 jam (e); suhu proses RVA (g)

Tabel 4. Sifat pasta tepung native dan sampel termodifikasi ${ }^{*}$

\begin{tabular}{|c|c|c|c|c|c|c|}
\hline Sampel & $\begin{array}{c}\text { Pasting } \\
\text { Temp. ( } \mathrm{C})\end{array}$ & $\begin{array}{l}\text { Puncak Viskositas } \\
\text { (cP) }\end{array}$ & $\begin{array}{l}\text { Holding Viscosity } \\
\text { (cP) }\end{array}$ & $\begin{array}{l}\text { Cold Viscosity } \\
\text { (cP) }\end{array}$ & $\begin{array}{l}\text { Breakdown } \\
\text { (cP) }\end{array}$ & $\begin{array}{l}\text { Setback } \\
\text { (cP) }\end{array}$ \\
\hline Native & $82,64 \pm 0,04^{b}$ & $3791,50 \pm 3,54^{\mathrm{a}}$ & $2178,00 \pm 5,66^{\mathrm{a}}$ & $4351,50 \pm 48,79^{a}$ & $1613,50 \pm 9,19^{a}$ & $2173,50 \pm 54,45^{\mathrm{a}}$ \\
\hline $\mathrm{M} 2 \mathrm{OH} 10$ & $90,21 \pm 0,06^{a}$ & $1977,00 \pm 69,30^{\mathrm{b}}$ & $1832,50 \pm 0,71^{\text {ab }}$ & $3020,00 \pm 209,30^{\mathrm{b}}$ & $144,50 \pm 68.60^{\mathrm{b}}$ & $1187,50 \pm 208,60^{b}$ \\
\hline M50H8 & $82,73 \pm 1,73^{b}$ & $1209,50 \pm 171,83^{c}$ & $1199,00 \pm 173,95^{c}$ & $2047,50 \pm 204,35^{c}$ & - & $848,50 \pm 30,41^{\mathrm{bc}}$ \\
\hline $\mathrm{M} 5 \mathrm{OH} 10$ & $84,04 \pm 0,72^{b}$ & $1094,00 \pm 196,58^{\mathrm{c}}$ & $1051,00 \pm 164,05^{c}$ & $1776,50 \pm 246,78^{c}$ & - & $725,50 \pm 82,73^{c}$ \\
\hline $\mathrm{U} 2 \mathrm{OH} 10$ & $89,62 \pm 0,22^{a}$ & $1914,00 \pm 65,05^{b}$ & $1777,00 \pm 1,41^{\mathrm{b}}$ & $2844,50 \pm 231,22^{b}$ & $137,00 \pm 63,64^{b}$ & $1067,50 \pm 229,81^{\mathrm{bc}}$ \\
\hline U2OH12 & $89,74 \pm 0,53^{\mathrm{a}}$ & $2003,50 \pm 338,70^{b}$ & $1811,00 \pm 274,36^{\mathrm{ab}}$ & $3020,00 \pm 558,61^{b}$ & $192,50 \pm 64,35^{\mathrm{b}}$ & $1209,00 \pm 284,26^{b}$ \\
\hline
\end{tabular}

Keterangan: *data dengan superscript berlainan dalam satu kolom maka berbeda secara signifikan $(P<0,05)$

Tepung/pati seperti tepung beras dengan perlakuan ultrasonikasi-HMT dan gelombang mikro kadar air 20\%-HMT 10 jam yang memiliki puncak viskositas rendah serta nilai setback yang cukup tinggi sesuai untuk produk breakfast cereal yang menghendaki kerenyahan dan tidak menghendaki penyerapan air berlebih saat dikonsumsi. Oleh karena itu pengembangan tepung beras patah dan menir termodifikasi dapat memberikan alternatif bahan baku fungsional yang sesuai bagi produk pangan tertentu.

\section{KESIMPULAN}

Kombinasi perlakuan ultrasonikasi dan gelombang mikro dengan HMT efektif menghasilkan tepung beras dengan kadar RS lebih tinggi. Namun peningkatan pada kombinasi perlakuan ultrasonikasi-HMT dan gelombang mikro-HMT masih lebih rendah dibandingkan peningkatan kadar RS pada perlakuan HMT selama 12 jam. Perlakuan kombinasi yang diberikan meningkatkan suhu awal gelatinisasi, menurunkan kekentalan pasta, nilai breakdown dan nilai setback. Perlakuan kombinasi ultrasonikasi dan gelombang mikro dengan HMT menyebabkan pembesaran agregat granula, membuat permukaan agregat lebih porous serta menurunkan rasio kristalinitas.

\section{UCAPAN TERIMA KASIH}

Penulis mengucapkan terima kasih kepada South East Asian Regional Center for Graduate Study and Research in Agriculture (SEARCA) yang telah mendanai penelitian ini, serta kepada Institut Pertanian Bogor (IPB) dan Balai Besar Penelitian Tanaman Padi (BB Padi) atas segala dukungan yang diberikan selama berlangsungnya penelitian.

\section{DAFTAR PUSTAKA}

[AOAC] Association of Official Analytical Chemistry. 2005. Official method of analysis. 18th Edition. Chapter 32, 46-70. Cereal Foods. Association of Official Analytical Chemistry International, Washington D.C. 
Adebowale KO, Afolabi TA, Olu-Owolabi BI. 2005. Hydrothermal treatments of finger millet (Eleusine coracana) starch. Food Hydrocolloid 19: 974-983. DOI: 10.1016/j.foodhyd.2004.12. 007.

Ahza AB, Faridah DN, Kusbiantoro B, Ardhiyanti SD. 2016. Physical Process Performance and Methods To Enhance Resistant Starch of Broken Rice Flour. Presented at International Conference Food Innovations: ASEAN Economic Community (AEC) Challenges 2016. Jakarta International Expo, September 21st-23rd 2016.

Ambigaipalan P, Hoover R, Donner E, Liu Q. 2014. Starch chain interactions within the amorphous and crystalline domains of pulse starches during heat-moisture treatment at different temperatures and their impact on physicochemical properties. Food Chem 143: 175-184. DOI: 10. 1016/j.foodchem. 2013.07.112.

Anderson AK, Guraya HS. 2006. Effects of gelombang mikro heat-moisture treatment on properties of waxy and non-waxy rice starches. Food Chem 97: 318-323. DOI: 10.1016/j.food chem.2005.04.025.

Belitz HD, Grosch W, Schieberle P. 2009. Food Chemistry 4th Revised and Extended Edition. 315-327. Springer-Verlag, Berlin, Heidelberg.

BeMiller JN. 2007. Carbohydrate Chemistry for Food Scientists Second Edition. Minnesota (USA): AACC International Press.

Birt DF, Boylston T, Hendrich S, Jane JL, Hollis J, Li L, McClelland J, Moore S, Phillips GJ, Rowling M, Schalinske K, Scott MP, Whitley EM. 2015. Resistant starch: promise for improving human health. Adv Nutr 4: 587-601. DOI: 10.3945/an.1 13.004325

Bizkup RC, Rokita B, Lotfy S, Ulanski P, Rosiak JM. 2005. Degradation of chitosan and starch by 360-kHz ultrasound. Carbohyd Polym 60: 175184. DOI: 10.1016/j.carbpol.2004.12.001.

Brouns F, Kettlitz B, Arrigoni E. 2002. Resistant starch and the butyrate revolution. Trends Food Sci Technol 13: 251-261. DOI: 10.1016/S09242244(02)00131-0.

[BSN] Badan Standardisasi Nasional. 2015. SNI Beras (SNI 6128:2015). Jakarta.

Cham S, Suwannaporn P. 2010. Effect of hydrothermal treatment of rice flour on various rice noodles quality. J Cereal Sci 51: 284-291. DOI: 10.1016/j.jcs.2010.01.002.

Chung HJ, Liu Q, Hoover R. 2009. Impact of annealing and heat-moisture treatment on rapidly digestible, slowly digestible and resistant starch levels in native and gelatinized corn, pea and lentil starches. Carbohyd Polym 75: 436-447. DOI: 10.1016/j.carbpol.2008.08.006.

de Souza D, Sbardelotto AF, Ziegler DR, Marczak LDF, Tessaro IC. 2016. Characterization of rice starch and protein obtained by a fast alkaline extraction method. Food Chem 191: 36-44. DOI: 10.1016/j.foodchem.2015.03.032.

Hoover R. 2010. The impact of heat-moisture treatment on molecular structures and properties of starches isolated from different botanical sources. Crit Rev Food Sci 50: 835847. DOI: $10.1080 / 10408390903001735$.

Htoon A, Shrestha AK, Flanagan BM, Lopez-Rubio A, Bird AR, Gilbert EP, Gidley MJ. 2009. Effects of processing high amylose maize starches under controlled conditions on structural organisation and amylase digestibility. Carbohyd Polym 75: 236-245. DOI: 10.1016/j.carbpol. 2008.06.016.

Hung PV, Chau HT, Phi NTL. 2016. In vitro digestibility and in vivo glucose response of native and physically modified rice starches varying amylose contents. Food Chem 191: 7480. DOI: 10.1016/J.FOODCHEM.2015.02.118.

Jambrak A, Herceg Z, Šubaric' D, Babic' J, Brnc 'ic' M, Brnc 'ic' SR, Bosiljkov T, C` vek D, Tripalo B, Gelo J. 2010. Ultrasound effect on physical properties of corn starch. Carbohyd Polym 79: 91100. DOI: 10.1016/j.carbpol.2009.07.051.

Jiang Q, Xu X, Jin Z, Tian Y, Hu X, Bai Y. 2011. Physicochemical properties of rice starch gels: Effect of different heat treatments. J Food Eng 107: 353-357. DOI: 10.1016/j.jfoodeng.2011. 07.006 .

Jiranuntakul W, Puttanlek C, Rungsardthong V, Punchaarnon S, Uttapap D. 2011. Microstructural and physicochemical properties of heat-moisture treated waxy and normal starches. J Food Eng 104: 246-258. DOI: 10.1016/j.jfoodeng.2010.12.016.

Kaur B, Ariffin F, Bhat R, Karim AA. 2012. Progress in starch modification in the last decade. Food Hydrocolloid 26: 398-404. DOI: 10.1016/j.food hyd.2011.02.016.

Kiatponglarpa W, Tongtaa S, Rolland-Sabatéb A, Buléonba A. 2015. Crystallization and chain reorganization of debranched rice starches in relation to resistant starch formation. Carbohyd Polym 122: 108-114. DOI: 10.1016/j.carbpol. 2014.12.070.

Klein B, Pinto VZ, Vanier NL, Zavareze ER, Colussi R, Evangelho JA, Gutkoski LC, Dias ARG. 2013. Effect of single and dual heat-moisture treatments on properties of rice, cassava, and 
pinhao starches. Carbohyd Polym 98: 15781584. DOI: 10.1016/j.carbpol.2013.07.036.

Leewatchararongjaroen J, Anuntagool J. 2016. Effects of dry-milling and wet-milling on chemical, physical and gelatinization properties of rice flour. Rice Sci 23: 274-281. DOI: 10.1016/j.rsci.2016.08.005.

Pinto VZ, Vanier NL, Deon VG, Moomand K, El Halal SLM, Zavareze ER, Lim LT, Dias ARG. 2015. Effects of single and dual physical modifications on pinhao starch. Food Chem 187: 98-105. DOI: 10.1016/J.FOODCHEM.20 15.04.037.

Pratiwi M. 2016. Structural Changes of Arrowroot Starch (Marantha arundinacea L.) as the Impact of Multiple Treatments by Acid Hydrolysis, Debranching, Autoclaving-cooling Cycles, and Heat Moisture Treatment (HMT). [Thesis]. Sekolah Pascasarjana. Institut Pertanian Bogor.

Pukkahuta C, Shobsngob S, Varavinit S. 2007. Effect of osmotic pressure onstarch: new method of physical modification of starch. Starch/Stärke 58:78-90. DOI: 10.1002/star.200 600509.

Schmiedl D, Bauerlein M, Bengs H, Jacobasch G. 2000. Production of heatstable, butyrogenic resistant starch. Carbohyd Polym 43: 183-193. DOI: 10.1016/S0144-8617(00)00147-8.
Sujka M, Jamroz J. 2013. Ultrasound-treated starch: SEM and TEM imaging, and functional behaviour. Food Hydrocolloid 31: 413-419. DOI: 10.1016/j.foodhyd.2012.11.027.

Warren FJ, Gidley MJ, Flanagan BM. 2016. Infrared spectroscopy as a tool to characterise starch orderedstructure-a joint FTIR-ATR, NMR, XRD and DSC study. Carbohyd Polym 139: 3542. DOI: 0.1016/j.carbpol.2015.11.066.

Zavareze ER, Storck CR, Castro LAS, Schirmer MA, Dias ARG. 2010. Effect of heat-moisture treatment on rice starch of varying amylose content. Food Chem 121: 358-365. DOI: 10.1016/j.foodchem.2009.12.036.

Zeng F, Ma F, Kong F, Gao Q, Yu S. 2015a. Physicochemical properties and digestibility of hydrothermally treated waxy rice starch. Food Chem 172: 92-98. DOI: 0.1016/j.foodchem.20 14.09.020.

Zeng S, Wua X, Lin S, Zeng $\mathrm{H}$, Lua X, Zhang $\mathrm{Y}$, Zheng B. 2015b. Structural characteristics and physicochemical properties of lotus seed resistant starch prepared by different methods. Food Chem 186: 213-222. DOI: 10.1016/j.food chem.2015.03.143.

Zhou Y, Meng S, Chen D, Zhu X, Yuan H. 2014. Structure characterization and hypoglycemic effects of dual modified resistant starch from indica rice starch. Carbohyd Polym 103: 81-86. DOI: 10.1016/j.carbpol.2013.12.020. 